\title{
THE TSAR'S CAPITAL WITHOUT THE TSAR ACCORDING TO REPORTS FROM ST PETERSBURG TO THE IMPERIAL COURT OF VIENNA, 1716-1717*
}

\author{
Franziska Schedewie \\ Friedrich Schiller University Jena, \\ Institute for Historical Research, \\ Department of East-European Studies, \\ Jena, Germany
}

This article examines Peter I's second journey to Western Europe from the perspective of the Imperial resident Otto von Pleyer, who stayed behind in the tsar's new capital of St Petersburg and reported from there to the Imperial court of Vienna. What difference did it make, according to his reports, that the tsar was away on the road? Analysing two topics in the nineteen reports he made between February 1716 and October 1717 (the army, fleet, and the condition of the soldiers, as observed from St Petersburg, and artists, artisans, and architecture, especially the reception of the celebrated French architect Le Blond), the article concludes that themes of disharmony and dissipation on the one hand and accusations of irresponsibility and thoughtlessness on the other are so ubiquitous in Pleyer's reports that they create the impression of an acute potential threat and homemade crisis. The vacuum caused by the absence of the tsar itself, by rumors, and by constant wondering what the next step was increase the impression of a permanent latent crisis, even without the ultimate climax in the form of the flight of Tsarevich Aleksei. Furthermore, a close analysis of the two selected topics shows that the political problems were not isolated, but interdependent on the social and cultural spheres. With its additional research focus, the article contributes to previous research, especially that by Paul Bushkovitch. Pleyer's diplomatic reports convey a surprising degree of social criticism combined with a distinctive moral overtone. They provide a valuable source for the approaches of the New Diplomatic History.

Keywords: New Diplomatic History; Peter I; Otto von Pleyer; Jean-Baptiste Alexandre Le Blond; Alexander Menshikov; St Petersburg.

В статье рассматривается вторая поездка Петра І в Западную Европу с точки зрения австрийского дипломатического агента Отто фон Плейера, который жил в новой столице России и докладывал о происходящем венскому императорскому двору. Как поменялось положение вещей в стране в отсутствие

${ }^{\star}$ Citation: Schedewie, F. (2018). The Tsar's Capital without the Tsar According to Reports from St Petersburg to the Imperial Court of Vienna, 1716-1717. In Quaestio Rossica, Vol. 6, № 3, p. 696-710. DOI 10.15826/qr.2018.3.322.

Цитирование: Schedewie F. The Tsar's Capital without the Tsar According to Reports from St Petersburg to the Imperial Court of Vienna, 1716-1717 // Quaestio Rossica. Vol. 6. 2018. № 3. P. 696-710. DOI 10.15826/qr.2018.3.322.

(c) Schedewie F., 2018

Quaestio Rossica • Vol. 6 • 2018 • № 3, p. 696-710 
царя? Автор обращается к двум темам, отраженным в 19 донесениях Плейера с февраля 1716 г. по октябрь 1717 г., - состоянию армии и флота, а также личного состава, о котором автор донесений мог судить, находясь в Петербурге, и к событиям, происходившим в среде художников, ремесленников и архитекторов, в частности, приему прославленного французского архитектора Ж.-Б. Леблона. Делается вывод о том, что донесения Плейера полны ощущения дисгармонии и разобщения, отсутствие Петра он рассматривает как проявление безответственности, что производит впечатление нарастающей угрозы стабильности в стране и может повлечь за собой полномасштабный внутренний кризис. Вакуум, образовавшийся в отсутствие царя, домыслы, касавшиеся его планов, усугубляли эти настроения в стране, только усилившиеся в результате бегства царевича Алексея. Подробный анализ позволяет сделать вывод о том, что политические проблемы развивались в зависимости от социальной и культурной сферы. В исследовании затронуты новые аспекты предмета изучения в дополнение к уже существующим. Дипломатические донесения Плейера имеют морализаторское звучание и отражают критические настроения общества. Изучаемый материал является ценным источником для новой дипломатической истории.

Ключевые слова: новая дипломатическая история; Петр I; Отто фон Плейер; Жан-Батист Александр Леблон; Александр Меншиков; Санкт-Петербург.

In terms of diplomatic hierarchy, Otto von Pleyer - a steady reporter to the Imperial court of Vienna1 - was just a resident in the new Russian capital of St Petersburg in 1716-1717. Having lived there and in Moscow since 1692,2 he seems to have been the kind of person who had his eyes and ears everywhere and whom the 'bigheads' at the Petrine court like Alexander Menshikov enjoyed taking aside at festivities in order to tell some secret. In 1718, shortly after Peter I's return from his famous second journey to Western Europe [Liechtenhan, p. 381-399], Pleyer was forced to leave Russia, as he had been drawn too deeply into the diplomatic scandal surrounding the flight of Tsarevich Alexei and the alleged schemes of Peter's political opponents. We can read the dramatic, fascinating particulars of the tsarevich affair in Paul Bushkovitch's analysis [Bushkovitch, 2001, p. 339-425] (see also: [Ausstellungskatalog 2012; Massie, p. 575-576; Wittram, vol. 2, p. 346-405]), and it is Bushkovitch

${ }^{1}$ Pleyer's reports are archived in the Haus-, Hof- und Staatsarchiv in Vienna; for the years 1716/1717: HHStA Rußland I, Karton 24 [in the following: HHStA Rußland I 24]. As for further information on and publications of his reports see below, fn. 3, as well as (for 1710) [Herrmann, p. VI-VIII, 118-140], also for 1710 [Лавры Полтавы]. See also: [Устрялов, т. 1, p. 83]. Unlike the diplomatic correspondence from Prussia, Saxony, France, or England, those from the Imperial court in Austria were not extensively edited in SIRIO [Сборник Императорского Русского Исторического Общества], although the occasional exchange of documents took place, see: [РГИА. Ф. 746. ОП. 1. Д. 180. Л. 157-158] (Transmission to the Russian Historical Society of a report by Schoenborn to Charles VI on his meeting with Peter I at Braunschweig; letter written by archivist Schrauf, Vienna, 1 May 1890). See also: [Русское историческое общество, с. 83].

${ }^{2}$ For biographical information on Pleyer, see: [Лавры Полтавы, с. 428-430; Устрялов, т. 1, с. 84-85, т. 6, с. 79-81; Агеева, с. 131-132, 568, 637-639] (on Pleyer's promotion from secretary to resident). 
who has emphasised the link between this affair and the new rise of Menshikov as the tsar's person of trust in the conflict with the Senate [Bushkovitch, 2001, p. 339-371]. In this context of faction and prosecution, important passages from Pleyer's reports have been edited in Bushkovitch's book. The present paper seeks a complementary approach to these and highlights further passages from Pleyer's unpublished reports ${ }^{3}$ by asking new questions. Firstly, considering the whole period of Peter's absence from St Petersburg between 7 February 1716 and 21 October 1717 (new style) [Luber, p. 118-122], what were the recurrent themes and topics in Pleyer's letters from the Russian capital? And secondly, with regards to a new appraisal of Peter's journey from the perspective of those who stayed behind at home, ${ }^{4}$ what difference did it make, as derived from Pleyer's reports, that the tsar was actually on the road?

In essence, this paper will conclude that themes of disharmony and dissipation on the one hand and accusations of irresponsibility and thoughtlessness on the other are so ubiquitous in Pleyer's reports that they create the impression of acute potential threat and homemade crisis. The vacuum caused by the absence of the tsar, rumours, and constant wondering what the next step was increase the impression of permanent latent crisis, even without the ultimate climax in form of Alexei's flight and even though Pleyer typically starts his reports by claiming that 'this was a time of solitude with the absence of the tsar and his court from St Petersburg, where nothing noteworthy ever happened' (e. g.: [HHStA Rußland I 24. F. 354 (04.06.1717)]). ${ }^{5}$

In order to substantiate the conclusion, two topics are going to be pursued: firstly, the state of the army and fleet ${ }^{6}$ as reported by Pleyer and, secondly, artists, artisans, and architecture. These topics are not randomly chosen. It is striking that Pleyer devoted rather more space to the military and even to social aspects like the distribution of goods or the gap between luxury and poverty (see below and, e. g.: [HHStA Rußland I 24. F. 365-366 (06.07.1717)] than

${ }^{3}$ This article is based on the analysis of Pleyer's original reports in HHStA Rußland I 24 (1716-1717), see above: [fn. 1]. These were provided in digitalized form by the open access online edition project at the German Historical Institute (DHI) Moscow [Relationen vom russischen]. Special thanks go to Dr Lorenz Erren (Univ. of Mainz) and Ernst Petritsch (HHStA Wien).

${ }^{4}$ This paper was first presented under the title of 'La cour de Saint-Pétersbourg sans le tsar, $\mathrm{d}$ 'après les relations destinées à la cour de Vienne' at the International Conference organised by Dominique-Francine Liechtenhan [Le deuxième grand voyage de Pierre le Grand en Europe].

${ }^{5}$ „Von hier allerunterthänigst zu berichten ist dieser Zeit her gar nichts alhier fürgefallen und zu hören gewesen, alwo man aniezo allein in einer einsamkeit lebet“.

${ }^{6}$ For the significance of the military under Peter I in general, see e. g.: [Cracraft, p. 40-143; Hughes, p. 63-91]; see also: [Taylor, p. 38-41].

7 "Vor etwa zwey Wochen entstunde in einen der Czarischen neuen Lusthäuser 30 werst von hier in Peterhoff, alwo die verwichene Jahre angekommene Franzosen kostbahre gärten, grotten, und Känälen anlegen, eine Feuersbrunst, wodurch unter anderen der armen aldort arbeitenden bauern und taglöhner ihre proviant bey 3000 grosse säke mehl und zweybacken verbrennet worden, derowegen umb die armen menschen nicht gar hungers sterben zu lassen, man alhier alles mehl aus denen Pude [?], und aus russland kommene Schiffe weggenommen und naher Petershoff gebracht, wodurch alhier widerumb ein grosser mangel an mehl entstanden, und dem gemeinen man sehr schwär geschihet..." - Like in this passage, Pleyer often describes the lavish lifestyles of the few as opposed to the poverty of the masses with a moral touch. 
to important individuals and their careers during the tsar's absence. ${ }^{8}$ In particular, it will be shown that the celebrated French architect Jean-Baptiste Alexandre Le Blond ${ }^{9}$ played his own notorious role in the scenarios of Pleyer's reports.

To start with, Pleyer was able to write his reports from the capital because, contrary to his first intention and unlike the representatives of Saxony and Denmark, he stayed there and did not follow the tsar westwards. In his first report after Peter's departure, he gives an account of how he went to see both the chancellor and vice-chancellor immediately in order not only to ask for a leave of absence and wish them a good journey, but also to ask what orders His Majesty had issued concerning foreigners and whether they were allowed or obliged to accompany him. Pleyer writes that the residents (unlike the envoys) were free to decide whether they wanted to follow up to Riga: however, he believed that by the time of his arrival in Riga, the tsar would already be gone. Last but not least, Pleyer remained in St Petersburg due to the lack of horses: they had all been taken by the tsar's entourage [HHStA Rußland I 24. F. 264-265 (10.02.1716)]. ${ }^{10}$

The same shortage of horses applied for Peter I's return. This time, Pleyer reports that soldiers had had to walk by foot all the way from Poland. They had had to leave their horses with other troops. As for the socalled relay-horses, they had all been hired out before the expected arrival of the tsar [HHStA Rußland I 24. F. 369 (20.09.1717)]. ${ }^{11}$

\footnotetext{
${ }^{8}$ One report mentions a rivalry for influence between Shafirov and Matveev (laconically summarised in Vienna as "Der Mattveoff wurde von dem Schaffiroff aus allen Geschäfften gehalten" on the back of Pleyer's file [HHStA Rußland I 24. F. 274], referring to Pleyer's report of 27 March 1716). The same report, and again only this one, goes into the alleged choice of the controversial metropolitan of Riazan' (Stefan Iavorskii) as new patriarch [Ibid., p. 272-274]. See: [Bushkovitch, 2001, p. 350-351]. Other references in Pleyer's reports to certain individuals or to the 'old families' ("die alte Familien" [Ibid. F. 374 (22.10.1717)]; deciphered) and their members are not discussed here, as they are analysed, like the affair of Alexei Petrovich, by Bushkovitch.

${ }^{9}$ On architecture and Le Blond in particular, see: [Corboz, p. 10-574; Игнатова, c. 161162; Massie, p. 521-525; Medvedkova]. None of these studies specifically refer to Le Blond in Pleyer's reports. See also the paper by Roksana Rebrova [Реброва].

${ }^{10}$ Gleich nach der abreis des Czaren gieng ich zu den groß-Canzler, und vicekanzler mich von ihnen zu beurlauben, und glück auf ihre reis zu wünstschen [sic!]. Anbey mich zu erkundigen, waß ihro Czarische May[estät] wegen uns frembden für ordres ihnen hinterlassen haben; ob wir ihme naher Riga folgen sollen, oder dörften? Worauf sie beyde mir vermeldeten, was den Königl[ich] dänischen, und Pohlnisch-Sachsischen als extraordinarios Ministros anbelange, hätte I[hro] May[estät] diesen beyden schon vor 2 wochen bedeuten lassen, daß dieselben ihro bis in Deutschland nachfolgen sollen; uns Residenten aber betreffend, hätte der Czar ihnen anbefolhen zu sagen, wann wir demselben in deutschland nachfolgen wollten, stünde uns zwahr frey, und wäre ihro nicht zuwider; wofern wir aber demselben nur bis Riga folgen, und begleiten wollten, alwo er nicht gesinet wäre sich lang aufzuhalten, sondern nach anlangung der Czarin und Kanzley seinen [?] weg naher deutschland hinaus zu beschleinigen, würden wir ihn schwärlich über 2 oder 3 tag aldort sehen, oder gar nicht mehr in Riga antreffen, also umbsonst uns die müehe nemmen dahin nachzureisen. Weilen nun bey vielen abreisenden Hofbedienten keine relaispferd auch umb das größe geld zu bekommen, mit eigenen aber unmöglich den Czaren mehr einzuholen, und in Riga anzutreffen ist, er auch solche verständlich genug hat wollen ablöhnen, als bin ich, der Hollandische, und Hanoverische minister alhir verblieben, alwo uns das ganze Jahr hindurch, weilen der Czar vor Weihnachten nicht zurückzukehren gesinnet seyn solle, in einer rechte einsambkeit die zeit zimblich lang fallen wird."

11 „Diese Leute seind aus Pohlen bis hirher zufueß komen, weilen sie ihre Pferde (dan es dragoner regimenter seind) ihren unberittenen Cameraden haben zurücklassen müssen. Durch ganz Liiffland, und Kurland seind nun schon die relaispferde zu des Czaren ankunft bestellet, welchen man gegen mitten des monaths October alhier erwartet."
} 


\section{Army and fleet}

This last observation leads to the first topic: soldiers and the state of the army as reported by Otto von Pleyer. Indeed, the army and fleet, the condition of soldiers, ammunition, ships, and ports are constantly repeated elements of description in all of Pleyer's 19 reports archived in box No. 24 in Haus-, Hof- und Staatsarchiv Vienna during Peter I's second journey. Obviously, this topic provided Pleyer with the means to "kill two birds with one stone': any news on the state and strength of the tsar's armed forces was of primary interest to the Imperial court. Equally, by writing about the army, Pleyer was able to depict the problems at the top of the Russian state.

His initial focus was on troops in Finland and ships to be sent to Denmark. Both of these issues and endeavours are described as thoroughly desperate and highly expensive, especially in terms of human life. This is what can be read in almost the first report of this period: an order had gone to the tsar's dispensary that the feldshers needed more material than usual, which meant, according to Pleyer's explicit interpretation, that a big operation was under way that would cost a lot of people - in his German words: "viel volk kosten dörffen" [HHStA Rußland I 24. F. 273 (27.03.1716)]. ${ }^{12}$

In Finland, again according to the original words of Pleyer, troops were melting away [HHStA Rußland I 24. F. 281 (03.07.1716)]. ${ }^{13}$ Pleyer does not merely count figures (e. g.: [HHStA Rußland I 24. F. 344 (26.03.1717)]). ${ }^{14}$ He employs all possible terms to describe the deplorable state of these soldiers and why they were dying of illness and bad food. One of Pleyer's reports, of which the enciphered part is published in a long passage by Bushkovitch, is dated 22 February 1717. The edited ciphertext contains alarming hints at possible unrest in St Petersburg, caused by united opposition [Bushkovitch, 2001, p. 366, fn. 49]. The political use of this secret, encrypted information eventually caused a diplomatic scandal one year later. Yet, the same report also contains the news that 200 men had frozen to death as they were repairing ships in the ice-cold winter sea [HHStA Rußland I 24. F. 331-332 (22.02.1717)]. ${ }^{15}$

12 „Er hat eine ordre an die Czarische Haubtapoteken anhero gesendet, daß man für diese Campagne die feldapoteken, und die feldscherer feldkasten mit mehreren medikamenten, und materialien, als sonsten gebrauchlich versehen solle. Worauf gemuthmaßet wird, daß bey den fürhabenden einfall über den Sinus Bothnicum in Schweden große operationes fürgenommen werden sollen, und viel volk kosten dörffen."

${ }_{13}$ „Aus Finland ist noch nicht das geringste andere zu hören, als daß aldort wegen elende lebensmitteln die armee fast ganz zerschmelzet..."

${ }^{14}, \ldots$ als auch die armée in Finland, welche vergangene Campagne bis gegen 10000 man abgenommen hat..."

${ }^{15}$ „Ewer Kay[serlichen] und König[lichen] Kathol[ischen] May[estät] allerunterthänigst treugehorsambst zu berichten, daß seit meine letzten der Admiral sambt den fürsten Menschicoff, welcher dem erstern bald naher Revel gefolget, vorige wochen von dann zurück anhero kommen ist, von deren leuten nun zu vernemmen ist, daß sie aldar befunden, wo biß zum aufgehenden wasser für die alda ligende schiff an den Hafen keine andere deffension wider den Eysgang zu machen, als daß man in einer zimblich weite das Eys allenthalben aufgehaket, die schiff losgemachet, und so viel denen noch über wasser gestanden, oder flot 
The passage actually looks ambiguous in the sense that it is hard to distinguish whether Alexander Menshikov was deliberately blamed in this letter for the inhumane treatment of these poor labourers. In other reports, however, Menshikov is certainly often presented in the kind of favourable light that he would probably have chosen for himself: as a single, energetic man who clashed with the Senate on the grounds that the Senate - while in charge of the government during Peter's absence - refused to take up its responsibility and provide for the army. In his previous letter of 25 November 1715, when rumours about the planned journey were beginning to spread and Menshikov was still out of favour with Peter, Pleyer had described the full allocation of competence to the Senate, leaving Menshikov alone and without power, as something generally seen as sensational [HHStA Rußland I 23. F. 2099 (25.11.1715)]. ${ }^{16}$ Now, with the tsar absent, Pleyer repeatedly refers to accusations against the Senate as harming the tsar's and the country's true interests. The letter in which he explicitly correlates a loss of trust and credit on the part of the Senate with the new rise of Menshikov is from 12 October 1716: Menshikov might even become viceroy (in contrast to his previous prosecution), a turn that, according to Pleyer, was probably due to the Senate keeping all provisions for itself, risking starvation at home and in Finland, while Menshikov alone had taken measures to save the people from complete ruin. ${ }^{17}$ It is this letter that also reports that Menshikov was ordered by Peter to send him the tsarevich [HHStA Rußland I 24. F. 299-300 (12.11.1716)]. ${ }^{18}$ Here is the link with Menshikov being Peter's person of trust, as pointed out and analysed by Bushkovitch [Bushkovitch, 2001, p. 352-8].

Speaking of trust and the severe accusation of neglect against the Senate, in another letter of 6 September 1717, shortly before Peter's return, Pleyer reports the Senate's effort to count all troops in the country [HHStA

gewesen, von ein ander geführet, damit das Eys darzwischen hindurch zu gehen mehrer plaz habe, wan es ein wind darauf zuetreiben würde. Welches zwar auf ein werk gerichtet worden, weilen aber zeit dieser arbeit gähling [?] ein starker wind auf der see entstanden, daß wasser aufgetrieben, daß es über das Eys gangen, und die arbeiter also im wasser arbeiten müssen, darauf eine grimmige Kälte eingefallen, welche noch so hefftig, als fast im großen winter anno 1708 gewesen anhaltet, so sind der armen Leute 200 man auf einmahl erfrohren."

16 "....wobey dieses für etwaß sonderliches alhier viel observiret worden, daß bey diesen Vorhabenden reisen des gantzen Hofes der Fürst Menschicoff alhier zurück allein, und zwahr ohne einziges sonderliches pouvoir, welches der Senat yber alles vollkommen haben solle, zurückbleiben dörffe müssen."

${ }^{17}$ See the interpretation and the edited passage in [Bushkovitch, 2001, p. 356-357, fn. 31]. Pleyer's most explicit sentence is the following: "Übrigens bekomet es alhier daß ansehen, als ob der Senat, welcher zeit her den Czaren repraesentirte, und in regirungs sachen allen pouvoir hatte, auch widerumb herunter komen, und laut noch alhier in geheimb gehenden reden der fürst Menschicoff, dessen macht, und vorige grosse authoritet von der zeit der lezt gehaltenen Inquisition, gar umb viles gefahlen gewesen, widerumb empor kommen, und villeicht nechstens viceroy über daß ganze russische reich erkläret werden dörfte“ [ Ibid.].

$18 \ldots$ „...daß bald nach abgang voriger post des anderen tages frühe ein Courier vom Czaren aus Dänemark an den fürsten Menschikoff ankomen ist, welcher demselben pressante ordre mitbrachte, daß derselbe den Kron Prinzen, welcher laut beygelegten Brief naher Koppenhagen zu kommen, beruffen ist, ohne einzigen anstandt, und verweilung von hier expedieren sollte..." 
Rußland I 24. F. 365 (06.09.1717)]. ${ }^{19}$ The way Pleyer adds his remark that "various thoughts were being indulged in here [as to] why this calculation should be going on at the very moment" [Ibid.] might imply that he was actually hinting at the possible preparation of a coup.

Lastly, the army's rank and file appeared amply in Pleyer's reports, and not merely as movable, pitiable objects, but also as actors in their own right and with their own agency. Pleyer points out in July 1717 that there was a great risk of upheaval if troops should be left hanging around in great numbers without any proper duties or commissions [HHStA Rußland I 24. F. 360 (16.07.1717)]. ${ }^{20}$ Two months later, in the letter of 6 September 1717 just mentioned above, he reports that soldiers were being employed for building roads and bridges and cutting woods [Ibid. F. $366(06.09 .1717)]$. Two weeks later, he already speaks of them as voicing their discontent in public: they had served the tsar as true soldiers against his enemies, Pleyer literally repeats their complaints, and had taken part in many tough actions. That is why they had consoled themselves with the prospect of different treatment than working as day labourers and dying of starvation [Ibid. F. 369 (20.09.1717)]. ${ }^{21}$

There is a strong resemblance here to the situation of 1698 and the second upheaval of the streltsy: they, too, had found themselves at the end of a military campaign; they, too, had experienced (albeit a different) loss of status, against which they bitterly protested; and they, too, had acted in parallel to a political faction within the upper strata of society (of which they were probably not even aware) while the tsar was travelling in Western Europe. The resemblance of the two situations might even have appeared stronger from Pleyer's perspective than from ours today, depending on how aware he was of the difference between the common soldiers in 1717 and the all but extinguished status group of the streltsy. ${ }^{22}$

19 „Es hat der Senat alhier aus allen gouvernements eine accurate listam der aller orten sich wirklich befindlichen Czarischen regimenter und wie stark jedes bis zu einen man ist, einsenden lassen, aus welchen zu ersehen solle gewesen seyn, daß mit allen noch in Meklenburg gebliebenen, nun noch in Pohlen, und Preussen, in der Ukrain, in Moscovischen gouvernements, Liiffland, Kurland, Ingermankland, und Finland stehende trouppen gegen 80000 man ohne die garnisonen sich die czarische Miliz belauffen solle, welches alhier unterschiedliche gedanken machet, warumb diese berechnung, und nachfrag geschehen seyn möchte."

${ }^{20}$ „Wohin nun die aus den Mecklenburgischen zurückkommende russische trouppen sollten in Rußland verleget werden, wird die zeit geben. Dabey ist nicht ohne Ursach zubesorgen grosse unruhe im Land, wan die trouppen werden müßig, und ohne operation ligen sollen."

${ }^{21}$ „Von denen aus Deutschland zurückgekommenen regimentern seind widerumb vier zur arbeit in des Czaren Lusthauß Petershof commendiret worden, wie es auch mit anderen nachkommende in anderen orten bey durchgrabenen der Canalle geschehen sollte: worüber sie offentlich murren, sagende: sie hätten so geraume Zeit her als wahre soldaten wider ihre feind dem Czaren treue dienst geleistet, und manchen schwären actionen beygewohnet, derowegen sie ein anderes tractament, als taglöhner arbeit, und kothgraben verdienet zu haben, sich getröstet hätten, wobey sie nun künftig erst hungers crepieren müsen.". This is the report mentioned above: it goes on to say that the soldiers had had to walk all the way from Poland, see above, fn. 10. On the dangers of a discontented populace under conditions of factional struggle and power vacuum, see also [Bushkovitch, 2001, p. 369].

${ }^{22}$ For a new interpretation of the second upheaval of the streltsy see [Moutchnik, p. 197-222]. See also: [Bushkovitch, 1995, p. 80-120]. 


\section{Artists, artisans, and architecture: Le Blond}

Moving on to the second topic of this article, the contrast between the contexts of war and the conditions of the common soldiers and Pleyer's description of art, architecture, and artisans is not as big as one might expect. Pleyer particularly disliked the new French architect and shooting star JeanBaptiste Alexandre Le Blond. Immediately after a drastic account of how the army in Finland was diminished and how the poor people were suffering from a bad harvest, cold weather, and increased prices, being hardly able to pay for bread in March 1717, there follows a passage on Le Blond:

The new French architect is now beginning to tear down the tsar's Lusthäuser [summer houses], which a few years ago was built at a distance from here at the seaside, at an excruciating expense of money and the croaking death of poor day labourers; entire hills were removed, canals were dug, and there were 6,000 men working at one location alone last summer, and many of them died, and now these are being torn down and the canals refilled, and he is going to rebuild everything according to his own whim [HHStA Rußland I 24. F. 347 (26.03.1717)]. ${ }^{23}$

This is the way Le Blond is described from his first mention in Pleyer's reports onwards [HHStA Rußland I 24. F. 293 (27.07.1716)]. ${ }^{24}$

Le Blond had been engaged by the tsar in order to raise the distinction not only of himself but also of all the other craftsmen and artisans who had come to Russia [HHStA Rußland I 24. F. 297 (28.09.1716)], ${ }^{25}{ }^{26}$ Pleyer scoffs: however, his demands for money and supplies were outrageous. Here again, Menshikov moves into a favourable light - in contrast, as one may put it here, to the even bigger spendthrift Le Blond. He scolded the latter once more for talking of tearing down palaces, summer and garden houses, fortresses, and ports that had cost not only millions of roubles, but

${ }^{23}$ „Der neue französische Architect Le Blond fanget nun an die Czarische Lusthäuser, welche vor einen und anderen Jahren theils weit von hier an der see mit unsäglichen Unkosten an geld, und crepierung der armen taglöhner erbauet, ganze hohen und kleine Bergen abgetragen, durchgegraben, und Känälen geführet worden, wobey allein an ein ort vergangenen sommer yber 6000 menschen arbeiteten, deren vile dabey crepiert seind, in den grund zu reissen, die Känäle zu füllen, und zuezuwerffen, nach welchen er nach seinem Humeur alles von neue widerumb aufbauen wird.“

${ }^{24}$ „Heut frühe ist ein architect aus Frankreich namens Le Blom [sic!], welcher aldort der fürnembste soll gewesen seyn, und der Czar selbst an den Herzog v[on] Orleans umb ihn geschrieben, anhero kommen, sein tractament soll monathlich 1000 Rub[el] seyn, und hat ihn der Czar unterwegs mit seinen portrait von $2500 \mathrm{rub}[\mathrm{el}]$ zum willkomb beehret haben. Sonsten ist alhier dieser Zeit nicht das geringste berichtwürdige fürgefallen."

25 "Dieser Zeit her ist auch ein französischer, der rede nach, gar berühmter Architect namens Le Blond, welcher auf ordre des Czaren in Paris angenommen worden unterschiedlichen französischen Künstlern und Handwerksmeistern anhero kommen, welche allen diesen leuten, die elend und zerrissen sind, damit er sich und ihnen ein grosses ansehen und distinction von anderen schon vor seiner alhier in Czarischen diensten befindlichen dergleichen meister zu weg bringen möchte."

${ }^{26}$ For the latest contribution on the arrival of French artisans in St Petersburg, see: [Андреева]. 
also hundreds of thousands of men, who had all died like cattle of starvation, toil, and disease [HHStA Rußland I 24. F. 298 (28.09.1716)]. ${ }^{27}$

Pleyer reports one conversation between these two protagonists, in which Le Blond (after emphasising how devastated Parisian society found itself after the artists' departure) demanded an escort of 70 men to accompany him to all the places he was going to visit, as well as a decently prepared dining table at all times. Menshikov (countering that the tsar would rather have left the artists in Paris instead of causing such grief) replied that he himself, as governor and prince, was safely travelling with just three or four of his domestic servants and made do with a "cold kitchen" [Ibid. F. 297-298]. ${ }^{28}$ Pleyer writes that Le Blond had been recommended to Menshikov in a letter he carried from the tsar himself, but that Menshikov now intended to support all those who would complain about the brutal procedures of this man ("dieser Mensch") and to give assistance to a petition in which a German engineer tried to find this famous architect guilty of major architectural mistakes and lack of professional knowledge [Ibid. F. 298]. ${ }^{29}$

Finally, in April 1717, the tsar's answer to Le Blond's conceptional outlines arrived: he was ordered to dismiss the new projects and resume the old ones. However, Le Blond had already begun to tear down the old buildings, which were now to remain as ruins until the tsar returned; probably, says Pleyer, they would collapse altogether [[HHStA Rußland I 24. F. 357 $(30.04 .1717)] .^{30}$

\footnotetext{
27 „Von nichts anderen redete, als nur von niederreissen aller Pallais, Lust- und gartenhausern, Vestungen, und Hafen, welche alle doch ausser der Millionen geldes auch manches m/100 menschen, die alle von Hunger, Arbeit, und Krankheiten als das Viech dabey umbkommen sind“".

${ }^{28}, \ldots$ zum Schluss noch dieser beygefüget, dass fast ganz Paris über dieser Leute abreis geweinet hätte, worauf ihn der Fürst antwortete, was ihre grosse praetendirte Wissenschaft betreffe, werde es dem Czaren sehr lieb seyn, wan er so künstliche meister in sein Land bekommen habe: daß aber ganz Paris über deren abreiß sich also betrübet hätte, so hätte er sie lieber aldort gelassen haben, als solches leyd angerichtet. Weilen nun die, vermuthlich, so unvergleichliche Architect welcher aller orten, wohin er im Land die gebau oder gegend zu besehen reiset, eine Escorte von 40 dragonern, 24 Musquetierer und 6 Personen zu Pferd, umb ordre hin- und her zu schicken, allenthalben, wo er hinkomet zubereitete und mit anständig essen versehene tafeln zustehen praetendiret, der fürst ihm aber replicirte, dass er als gouverneur und ein fürst nur mit 3 oder 4 personen seiner domestiquen allenthalben sicher reisete und mit einer Kalten Küche versehen wäre.“

29 „...hat er sich schon anfangs also schlecht recommendiret, dass der Fürst, welchem dieser Mensch vom Czaren in eine mitgebracht, eigenhändigen Brief sehr nachdrücklich anbefohlen worden, alle die Jenige unterstüzet, welche über seine bestialische proceduren sich beschwären, und deren suppliquen, worinnen ein deutscher Ingeneur allhier diesen berühmten architect etliche grund- und Haubtfehler in der architectur zu beweisen, und einer unwissenheit in dieser sachen zu überführen trachtet, möglichst secundiret."

${ }^{30}$ „Nun ist auch die antwort vom Czaren auf der neuen französischen General Architect Le Blonde yberschikte projecten und risse zurückkommen, durch welche fast alle seine risse verworfen, und bey denen vorigen von anderen schon verfertigten zu verbleiben, und in denen bauen fortzufahren befohlen worden. Indessen aber hat dieser schon einige gebau, welche schon viele tausend rubel gekostet, angefangen niederzureißen, und zu verändern, welche nun in ihre ruinierte stand bis zur ankunft des Czaren liegen bleiben, und gar vollends zusamb fallen, als man alles wiederumb von Grund auf die vorige vom Czaren beliebte art wird bauen müssen, wodurch viele tausende umbsonst verwendet worden."
} 
It is not far-fetched to contend that the tsar himself is accused of thoughtlessness here. It was he who had hired Le Blond, and now he dismissed his work in the impulsive and excessive manner that has so typically been ascribed to Peter I. In this contemporary report of Pleyer's, the absent sovereign is described as quite blind to the conditions he created at home, namely distasteful ruins and a great waste of money and human lives. Even more so did the accusation of thoughtlessness apply, again with a discernible moral overtone, to how the many ordinary and unprivileged artisans and craftsmen were treated when they came to Russia: Pleyer's reports read as if Peter hired these individuals whenever he came across someone on his journey. When the poor folks arrived, they were left to their own fates, as, like with the army, the Senate would not take care of them [HHStA Rußland I 24. F. 293 (27.07.1716)], ${ }^{31}$ thereby, one might add, disobeying and thwarting the intentions of the absent tsar.

So, what happened in St Petersburg during the vacuum of the tsar's absence, as perceived through the lens of Pleyer's reports? Basically, as pointed out initially, there was a situation of disharmony and dissipation that extended not only into the political, but also the social and cultural spheres. The close analysis of Pleyer's reports underscores the interpretation of Bushkovitch (based on the same sources) that the obstinate Senate lost, while the fortunate Menshikov proved able to seize the opportunity and win. He restored himself as a person of trust and filled the vacuum created by the tsar's absence. This he eventually did (from October 1716 on) by launching one festivity after another, to which he invited everyone, as Pleyer explicitly notes: 'Russians and foreigners of all conditions, of both sexes, from the highest to the lowliest' (e. g.: [HHStA Rußland I 24. F. 300 (07.12.1716)]). ${ }^{32}$ Not only did Menshikov sustain a practice ascribed to Peter (including the heavy drinking) and thus demonstrate his loyalty; apparently, he also stood for Peter's policies as his true representative, or 'column' in the figurative

31 "Es seynd dieser Zeit her sehr viele Handwerker aus Dänzig und andere orte zu Wasser und Land anhero kommen, welche der Czar aldar angenommen, einige wenige reisegeld reichen lassen, und ihnen auf einige Jahre hinaus freyheit von allen gaben versprochen hat, weilen nun alle elendig gekleydet, alhier kein ort und wohnung zu so vieler menschen Unterkommen zu finden, derowegen sie auf des feld unter gesträuch haben sich aufhalten müssen, auch keine Lebensmitteln mehr haben, und der Senat sich ihrer gar nicht annehmen, oder eine Kopiken geben will, so crepiren die armen menschen elendig vor Hunger und Trübsal.". In another letter, Pleyer points out that the Senate was likewise against the enormous costs caused by the French architects [Ibid. F. 347 (26.03.1717)], a position in conformity with Pleyer's, albeit deriving from a different general attitude.

${ }^{32}$ „Verwichenen 4ten und 5ten Currentis... wurde den ersten Tag des fürsten Menschicoff, des andern Tages darauf der Czarin Namenstag mit mahl und feurwerk herrlichst celebriret, worzue alle russen und ausländer aller h[? - damaged paper, F. Sch.] Conditions, auch beyderley geschlecht vom Höchsten bis geringsten eingeladen, und erschienen seind, da wiederumb nach hiesigen gewohnheit bey allerorten gesperten [?] Thüren, und Thoren bis in die tiiefste Nacht stark getrunken worden." 
sense, in St Petersburg while the tsar was away. In July 1717, Pleyer writes that from Menshikov's discourse, it looked as if the (travelling) tsar's court was very annoyed by the Danish king. Apparently (although this passage of Pleyer's is vague), Menshikov went on to fill the vacuum caused by Peter's absence actively and visibly on the level of symbolic representation, since although the Danish representative was properly invited to a festivity in St Petersburg, he was not given a seat at the table [HHStA Rußland I 24. F. 360-361 (16.07.1717)]..$^{33}$ Pleyer's 19 reports of $1716-1717$ provide just a small window into a long and complex history of personal relationships at the Russian court around 1700, and they must not be over-interpreted; yet, the Austrian resident was an observer who sent hints and adumbration to his emperor. If he wrote that Menshikov took him aside at a feast, got a beaker of Hungarian wine, and said to him (enciphered), "I wish the tsar allowed me to go to Hungary; I wanted to attend with my brothers the campaign and Prince Eugene, since he is a Roman imperial prince, and so am I; he is a field marshal, and so am I" [HHStA Rußland I 24. F. 302 (12.10.1716)],,$^{34}$ perhaps he meant to indicate that Menshikov felt insecure in his position and was looking for a further safe option to become independent of fortune and ephemeral favour. ${ }^{35}$

However, these primarily political observations are not the only results to be drawn from a close study of Pleyer's reports. As indicated above, these are instructive as a showcase of the interdependence of the political, social, and cultural spheres (including the economic sphere present in Pleyer's reports, but left out in this paper). They thus provide a valuable source for a new diplomatic history approach. The analysis of the two selected topics of the army and artists, artisans, and architecture throws some light on Pleyer's attitude as a foreign resident and correspondent and reveals an attention to this interdependence as a significant characteristic and quality of his reports. The way he expounds how poor people at the bottom suffered from fateful military decisions at the top and from the fancies of a few agents of high culture (sometimes with both aspects combined, such as when soldiers were obliged to dig canals!) even displays a striking element of social

${ }^{33}$ „Aus des Fürsten Menschicoff discursen ist woll anzunehmen, daß der Czarische Hof mit den König in Dänemark sehr müßvergnüget ist, welcher auch am fest St. Petri et Pauli St. V. an den Verfahren gegen den dänischen Consul merklich abzunemen waar, welchem obwohlen er zum tractament ordentlich geladen gewesen, dennoch bey der zwar engen taffel kein raume, oder plaz gemachet worden sich hinzusezen, daß er also widerumb naher Haus gangen ist, ohne daß iemand umb ihn mehr gefraget hat."

34 "Da man bey disch von iezigen Kriegsoperation des Prinzen Eugenij in Ungarn eine weile discurrirete, und endlich von der Tafel aufstunde, so liesse sich der Fürst ein großes Deckelglass voll Ungarischen aufbruchwein [?] geben, nahme mich auf die Seiten, truncke mir zu und sagete: [enciphered:] Ich wünschte dass der Zar mir erlauben wolle nach Hungarn zu gehen, ich wolte mit meinen Brüdern dem Prinz Eugenio in der Campagna beywohnen, dann er ist Röm[ischer] Kay[serlicher] [?] fürst, ich auch, er ist FeldMarschall, Ich auch."

${ }^{35}$ It is noteworthy that this was the very letter of 12 October 1716 in which Pleyer described the turning point in Menshikov's standing in the relationship between him, the tsar, and the Senate. 
criticism. In Pleyer's reports of $1716-1717$, this is added to by a latent moral accusation that such developments were due to neglect of responsibility by those in charge: the senators, the 'General Architect' Le Blonde, partly Menshikov, and, last but not least, the absent tsar. ${ }^{36}$

So, life went on in the tsar's capital without the tsar, but there was also a recurrence of short-lived, unconfirmed gossip, particularly about peace and dynastic marriage projects, allegedly with more German princes or the Swedish king [HHStA Rußland I 24. F. 277 (04.04.1716)], ${ }^{37}$ and rumours about the imminent return of the tsar [HHStA Rußland I 24. F. 305 (13.11.1716) $].{ }^{38}$ Besides this, there was a great amount of delay and indecision. This can be seen in the case of Le Blond. The death of Peter's sister Nataliia Alekseevna provides another example. According to Pleyer - and against Russian tradition, as he states - her corpse had to be kept in strong alcohol for more than six months, as her funeral could not be arranged without the tsar's orders. ${ }^{39}$

${ }^{36}$ This interpretation corresponds with existing research in the literature on the topic of 'good government' in the early modern period, see, e. g.: [Löwe, p. 1-26].

${ }^{37}$ „Gleichfalls gehet aniezo alhir die starke red, daß der Czar für seine dritte Mämb, der witib jüngste Schwester auch eine Heirath mit einem abgetheilten Sachsischen fürsten draußen projectire.“; [Ibid. F. 354 (04.06.1717)]: „... weilen die russen durch gehemb gewisse nachricht zu haben fürgeben, dass der Czar in Frankreich den Frieden mit Schweden machen werde; davon alhir ein project spargiret wird, dass der Czar Petersburg, Narva und Revel sambt allen denen dependentien behalten, dem König in Schweden aber ganz Finland, das übrige Liiffland, und Kurland abtreten, und auch seines verstorbenen Brueders Tochter, die verwittibte Herzogin von Kurland an ihn verheiraten wollte“ [Ibid. F. 360 (16.07.1717)]: „... und munckelt man alhier stark von einen zwischen den Czaren und König von Schweden obseyenden particulairfrieden, dessen beyde bis auf die condition wegen Revel mit ein ander einig seyn sollten." - Of course, all this was news of primary interest and potentially major importance for the court in Vienna!

38 "Indessen ist auch vom Czaren eine ordre an den Senat anhero kommen, dass derselbe alle gouverneurs aus allen Provinzen des ganzen Czarischen Reichs anhero berueffen sollte, umb auf das Ende des Monaths Decembris unausbleiblig alh[ier] zu escheinen, woraus des Czaren ankunft auf das neue Jahre desto gewisser gemuthmaßet wird." As a matter of fact, Peter returned almost a year later.

39 Nataliia apparently died from complications with a hernia: “...worauf noch selbige nacht ein currier an den Czaren mit der nachricht abgeschiket worden, durch welchen man wegen ihrer begräbnis so woll, als wegen aufsicht auf die Junge Herrschaft weitere ordre erwartet. Der Körper wurde gleich des andern Tages, wieder der russen bisherigen gewohnheit, exentriret, und in starkesten Spiritus eingeleget, sonderlich weilen er von unbeschreiblichen falten [?] ist“ [HHStA Rußland I 24. F. 280 (03.07.1716); F. 344 (26.03.1717)]: „Für des Czaren verstorbene Schwester Princessin Natalia, welche noch in ihren gewesten Wohnung in starken Spirite immer aufbehalten wird, richtet man ein besondere begräbnußort zue." The same report contains information on the funeral of the prince who was born during the journey and brought back to St Petersburg: „ohne einziger Ceremonien und berueffung einiger frembden in aller Stille zur Begräbnis gebracht worden" [Ibid.]. This passage is interesting, as it contradicts the reliable evidence from other archival sources discussed in the paper of Aleksei Morokhin L'histoire du voyage de Pierre et Catherine en Allemagne de la fin de 1716 au début de 1717 (Archives d'État russe de documents anciens, Moscou) at the Conference in Paris, June 2017 (see above: [F. 4]).

A further interesting topic to be pursued elsewhere and on a broader source basis would be how Peter's absence from St Petersburg affected relations with the people of the peripheries of his empire. There are hints in Pleyer's reports that Kalmyks took independent action against the Turkish provinces, counting on the tsar's approval afterwards; see: [HHStA Rußland I 24. F. 356 (30.04.1717)], or [Ibid. F. 365 (06.09.1717)]. 
From this point of view and considering the delays, the imperial resident Otto von Pleyer displayed a remarkably pragmatic approach in one of his early reports of 1716 towards his superiors. When asked by Vienna to take care of some prisoners of war still being kept in Russia, Pleyer replied that since the tsar was absent, there was nothing he could do in St Petersburg at the moment. But then he added that since the tsar was himself approaching the emperor on his journey, some minister might as well be charged with putting in a word for the prisoners [HHStA Rußland I 24. F. 270 (17.02.1716)] ${ }^{40}$

\section{Список литературы}

Агеева О. Г. Дипломатический церемониал императорской России : XVIII век. М. : Новый хронограф, 2012. 894 с.

Андреева E. Второе европейское путешествие Петра I и приезд французских мастеров в Петербург // Quaestio Rossica. T. 6. 2018. № 1. C. 114-129. DOI 10.15826/ qr.2018.1.285.

Игнатова Е. А. Записки о Петербурге : Очерк истории города. СПб. : КултИнформПресс, 1997. 619 с.

Императорское Русское Историческое Общество : 1866-1916. Пг. : Экспедиция заготовления государственных бумаг, 1916. 193 с.

Лавры Полтавы : Юст Юль, Оттон-Антон Плейер / сост. В. Наумов. М. : Фонд Сергея Дубова, 2001. 459 с.

РГИА. Ф. 746. Оп. 1. Д. 180.

Реброва Р. Дворец Федора Апраксина и «образцовый дом» Ж.-Б. Леблона: деятельность французского архитектора в Петербурге по новым источникам // Quaestio Rossica. T. 6. 2018. № 1. C. 130-138. DOI 10.15826/qr.2018.1.286.

Устрялов Н. История царствования Петра Великаго : в 6 т. СПб. : Тип. ІІ Отд. СЕИВК, 1858. Т. 1. LXXXVIII + $400 \mathrm{c}$.

Ausstellungskatalog "Die Flucht des Zarewitsch" / Hrsg. von S. Gfrorner, M. Follner. Wien : Generaldirektion des Österreichischen Staatsarchivs, 2012. 48 S.

Bushkovitch P. Aristocratic Faction and the Opposition to Peter the Great: the 1690s // Forschungen zur Osteuropäischen Geschichte. 1995. № 50. P. 80-120.

Bushkovitch P. Peter the Great : The Struggle for Power, 1671-1725. Cambridge : Cambridge Univ. Press, 2001. 485 p.

Corboz A. Deux Capitales Françaises Saint-Pétersbourg et Washington. Gollion : Infolio Ed., 2003. 115 p.

Cracraft J. The Petrine Revolution in Russian Culture. Cambridge ; Mass. : The Belknap Press of Harvard Univ. Press, 2004. XII + 560 p.

HHStA. Rußland I. Karton 23, 24.

Hughes L. Russia in the Age of Peter the Great. N. Haven : Yale Univ. Press, 1998. XXIX $+602 \mathrm{p}$.

Le deuxième grand voyage de Pierre le Grand en Europe : le colloque (DHI Paris, University of Paris-Sorbonne, Archive MAE, 19-21 June 2017) // France Diplomatie

40 „Sehet also weilen in der abwesenheit des czaren und dess[en] Ministern alhier auch für ihn nicht hülfliches zu thun aniezo Bey Ewer Kays[erlichen] und König[lichen] Kath[olischen] May[estät] allergnädigsten ermessen und gefahlen, ob nicht dieselbe etwa bey des Czaren annäherung, und mit dero Ministris etwa ohne dem fürfallende negotiation dero dazue abzuschikende Ministro wegen erledigung des erstgemelten Cornet Johan Henrich Pfeyffer, und iezermahlen schlesischen Edelman Wilhelm Lindeimer sambt seinem nunmehro beyhabenden Eheliebsten eine fürsprach zuthun allerg[nädigst] anzubefelhen mildreichst geruhen wollten." All transcriptions and translations in the text and annotations are by Franziska Schedewie, if they are not quoted from other works and indicated as such. 
[website]. URL: http://www.diplomatie.gouv.fr/fr/archives-diplomatiques/actualites-etevenements-des-archives-diplomatiques/article/colloque-le-deuxieme-grand-voyage-depierre-le-grand-en-europe-19-21-06-17 (mode of access: 01.09.2017).

Liechtenhan F.-D. Pierre Le Grand - Le premier empereur de toutes les Russies. Paris : Tallandier, 2015. $688 \mathrm{p}$.

Löwe H.-D. Aufstände im Russischen Reich von Alt-Moskau bis zum Beginn Sowjetrußlands: Aspekte einer vergleichenden Interpretation // Volksaufstände in Russland : Von der Zeit der Wirren bis zur „Grünen Revolution“ gegen die Sowjetherrschaft / Hrsg. von H.-D. Löwe. Wiesbaden : Harrassowitz, 2006. S. 1-26.

Luber S. Reiseroute Peters des Großen 1716-1717 // Zar Peter der Große : die zweite große Reise nach Westeuropa 1716-1717 / Hrsg. von D. Alfter. Hameln : CW Niemeyer, 1999. S. 118-122.

Massie R. K. Peter der Große : Sein Leben und seine Zeit. Königstein im Taunus : Athenäum, 1982. $782 \mathrm{~S}$.

Medvedkova O. Jean-Baptiste Alexandre Le Blond. Architecte 1679-1719 : De Paris à Saint-Pétersbourg. Paris : Alain Baudry et Cie, 2007. 359 p.

Moutchnik A. Der "Strelitzen-Aufstand" von 1698 // Volksaufstände in Russland : Von der Zeit der Wirren bis zur „Grünen Revolution“ gegen die Sowjetherrschaft / Hrsg. von H.-D. Löwe. Wiesbaden : Harrassowitz, 2006. S. 197-222.

Relationen vom russischen Hof Berichte europäischer Diplomaten, 1690-1730 / Hrsg. von L. Erren, F. Schedewie. 2016. URL: http://quellen-perspectivia.net/de/russische_relationen/start (mode of access: 01.09.2017).

Russland unter Peter dem Grossen : Nach den handschriftlichen Berichten Johann Gotthilf Vockerodt's und Otto Pleyer's / Hrsg. von E. Herrmann. Leipzig : Duncker \& Humblot, 1872. $140 \mathrm{~S}$.

Taylor B. D. Politics and the Russian Army. Civil-Military Relations, 1689-2000. Cambridge : Cambridge Univ. Press, 2003. 355 p.

Wittram R. Peter I. Czar und Kaiser. Zur Geschichte Peters des Großen in seiner Zeit. 2 Bände. Göttingen : Vandenhoeck \& Ruprecht, 1964. $490+646$ p.

\section{References}

Ageeva, O. G. (2012). Diplomaticheskii tseremonial imperatorskoi Rossii. XVIII vek [The Diplomatic Ceremonial of the Russian Imperial Court. $18^{\text {th }}$ Century]. Moscow, Novyi Khronograf. 894 p.

Andreeva, E. (2018). Vtoroe evropeiskoe puteshestvie Petra I i priezd frantsuzskikh masterov v Peterburg [Peter I's Second European Journey and the Arrival of French Masters in St Petersburg]. In Quaestio Rossica. Vol. 6. No. 1, pp. 114-129. DOI 10.15826/ qr.2018.1.285.

Bushkovitch, P. (1995). Aristocratic Faction and the Opposition to Peter the Great: the 1690s. In Forschungen zur Osteuropäischen Geschichte. No. 50, pp. 80-120.

Bushkovitch, P. (2001). Peter the Great. The Struggle for Power, 1671-1725. Cambridge, Cambridge Univ. Press. 485 p.

Corboz, A. (2003). Deux Capitales Françaises. Saint-Pétersbourg et Washington. Gollion, Infolio Editions. 115 p.

Cracraft, J. (2004). The Petrine Revolution in Russian Culture. Cambridge, Mass., The Belknap Press of Harvard Univ. Press. XII +560 p.

Erren, L., Schedewie, F. (Hrsg). (2016). Relationen vom russischen Hof Berichte europäischer Diplomaten, 1690-1730. URL: http://quellen-perspectivia.net/de/russische_relationen/start (mode of access: 01.09.2017).

Gfrorner, S., Follner, M. (Hrsg.). (2012). Ausstellungskatalog "Die Flucht des Zarewitsch". Wien, Generaldirektion des Österreichischen Staatsarchivs. 48 S.

Herrmann, E. (Hrsg). (1872). Russland unter Peter dem Grossen. Nach den handschriftlichen Berichten Johann Gotthilf Vockerodt's und Otto Pleyer's. Leipzig, Duncker \& Humblot. 140 p. 
HHStA Rußland I. Karton 23, 24.

Hughes, L. (1998). Russia in the Age of Peter the Great. N. Haven, Yale Univ. Press. XXIX +602 p.

Ignatova, E. A. (1997). Zapiski o Peterburge. Ocherk istorii goroda [Notes on Petersburg. An Outline of the History of the City]. St Petersburg, KultInformPress. 619 p.

Imperatorskoe Russkoe Istoricheskoe Obshchestvo 1866-1916 [The Imperial Russian Historical Society 1866-1916]. (1916). Petrograd, Ekspeditsiya zagotovleniya gosudarstvennykh bumag. $193 \mathrm{p}$.

Le deuxième grand voyage de Pierre le Grand en Europe : le colloque (DHI Paris, University of Paris-Sorbonne, Archive MAE, 19-21 June 2017). (2017). In France Diplomatie [website]. URL: http://www.diplomatie.gouv.fr/fr/archives-diplomatiques/actualites-etevenements-des-archives-diplomatiques/article/colloque-le-deuxieme-grand-voyage-depierre-le-grand-en-europe-19-21-06-17 (mode of access: 01.09.2017).

Liechtenhan, F.-D. (2015). Pierre Le Grand - Le premier empereur de toutes les Russies. Paris, Tallandier. $688 \mathrm{p}$.

Löwe, H.-D. (2006). Aufstände im Russischen Reich von Alt-Moskau bis zum Beginn Sowjetrußlands: Aspekte einer vergleichenden Interpretation. In Löwe, H. D. (Hrsg.). Volksaufstände in Russland. Von der Zeit der Wirren bis zur ,, Grünen Revolution“ gegen die Sowjetherrschaft. Wiesbaden, Harrassowitz, S. 1-26.

Luber, S. (1999). Reiseroute Peters des Großen 1716-1717. In Alfter, D. (Hrsg.). Zar Peter der Große: die zweite große Reise nach Westeuropa 1716-1717. Hameln, CW Niemeyer, S. 118-122.

Massie, R. K. (1982). Peter der Große. Sein Leben und seine Zeit. Königstein im Taunus, Athenäum. 782 p.

Medvedkova, O. (2007). Jean-Baptiste Alexandre Le Blond. Architecte 1679-1719. De Paris à Saint-Pétersbourg. Paris, Alain Baudry et Cie. 359 p.

Moutchnik, A. (2006). Der "Strelitzen-Aufstand" von 1698. In Löwe, H.-D. (Hrsg.). Volksaufstände in Russland. Von der Zeit der Wirren bis zur ,, Grünen Revolution “ gegen die Sowjetherrschaft. Wiesbaden, Harrassowitz, S. 197-222.

Naumov, V. (Comp.). (2001). Lavry Poltavy. Yust Yul', Otto-Anton Pleier [The Laurels of Poltava. Yust Yul, Otto Anton Pleyer]. Moscow, Fond Sergeya Dubova. 459 p.

Rebrova, R. (2018). Dvorets Fedora Apraksina I “obraztsovyi dom” Zh.-B. Leblona: deyatel'nost' frantsuzskogo arkhitektora $\mathrm{v}$ Peterburge po novym istochnikam [Fyodor Apraksin's Palace and J. B. Le Blond's "Model Home": New Data on the French Architect's Plans for St Petersburg]. In Quaestio Rossica. Vol. 6. No. 1, pp. 130-138. DOI 10.15826/ qr.2018.1.286.

RGIA [Russian State Historical Archive]. Stock 746. List 1. Dos. 180.

Taylor, B. D. (2003). Politics and the Russian Army. Civil-Military Relations, 16892000. Cambridge, Cambridge Univ. Press. 355 p.

Ustryalov, N. (1858). Istoriya tsarstvovaniya Petra Velikago $v 6 t$. [The History of the Reign of Peter the Great. 6 Vols.]. Vol. 1. St Petersburg, Tipografiya Vtorogo otdeleniya Sobstvennoi Ego Imperatorskogo Velichestva kantselyarii. LXXXVIII +400 p.

Wittram, R. (1964). Peter I. Czar und Kaiser. Zur Geschichte Peters des Großen in seiner Zeit. 2 Bände. Göttingen, Vandenhoeck \& Ruprecht. $490+646$ p.

The article was submitted on 15.03.2018 